\title{
空調熱負荷に影響を及ぼすオフィスの使われ方に関する研究 \\ A STUDY ON THE USE OF OFFICE SPACE AFFECTING AIR-CONDITIONING LOAD
}

\author{
石野久彌*, 郡 公子**, 佐藤 豊*** \\ Hisaya ISHINO, Kimiko KOHRI and Yutaka SATO
}

\begin{abstract}
It is important to assume the proper room conditions for simulating the air-conditioning load and the thermal sensation in a office building. But the reference data are not sufficient enough to assume the proper conditions relating to the use of office space. Three buildings have been researched to clear the fluctuation in occupancy and clothing insulation and to clear the number of machinery for office automation. We show the heat rates generated from office machinery in the researched buildings. These data become the useful reference both of for air-conditioning systen design and for simulation analysis on the air-conditioning load and the thermal sensation.
\end{abstract}

keyword:field survey, number of people that enter and exit from the entrance, number of occupant, intrinsic insulation of clothing, number of machinery for office automation, data for air conditioning system design

実測調査, 入退館者数, 在室人員数, 着衣量, O A 機器台数, 空調設計用資料

\section{1. 序}

オフィスビルの空調熱負荷や温熱感の変動をシミュレーションす る際に室の使われ方をいかに想定するかは重要な項目であるが、条 件設定の際に参考となるデー夕が十分といえない。本論文では、室 使用の項目の中でも、オフィスビルの在館・在室人員変動、着衣変 動、OA 機器類の設置密度と使用率などを研究対象とし、東京の才 フィスビル 3 棟の調査結果をまとめたものである。

オフィスビルの実態調查研究は過去に数々なされており、室使用 状態の調查を含むものも多いが、そのほとんどはエネルギーや室内 環境の解析のための付随データとして室使用状態が位置付けされて いる。そのため、調查項目が限定されていたり、ある建物のごく一 部のエリアに限られていたり、小規模の調査になる傾向がある。室 使用状態にかなりの重点を置いた研究としては、井上、野部らによ る研究で、空調への要求度と室の使われ方の関係に着目し、空調・ 照明面積率変動とともに在館・在室人員变動の調査を行ったもの ${ }^{1)}$ 、 伊藤、久野らによる研究で、室内環境実測と居住者アンケート調査 を行い、特に着衣量については、冬期の着衣量と年齢、暖房に対す る評価などを解析したもの ${ }^{2)}$ 、木村、李らによる研究で、在室人員 変動とOA 機器使用台数その他の消費電力量の変動を解析したもの ${ }^{32}$ などがある。
本論文は、筆者らがこれまで調査した䙡数のオフィスビルでの結 果について、調査した室床面積や調查人数が十分と判断しまとめた

\section{表 $-1 \quad$ 調査建物概要}

\begin{tabular}{|c|c|c|c|c|}
\hline 建物 & \multicolumn{4}{|c|}{ 概 要 } \\
\hline \multirow{6}{*}{$\begin{array}{l}N \\
ヒ ゙ \\
ル\end{array}$} & 所 & 東京都 & 敷地面積 & $21.280 \mathrm{~m}^{2}$ \\
\hline & 用 途 & 事務所(自社ビル) & 建築面積 & $6.370 \mathrm{~m}^{2}$ \\
\hline & 規 模 & 地上43階，地下4階 & 延床面稹 & $145.100 \mathrm{~m}^{2}$ \\
\hline & 種 & \multicolumn{3}{|l|}{ 電機メ一カ一本社 } \\
\hline & $\begin{array}{ll}\text { 就 } & \text { 業 } \\
\text { 時 } & \text { 間 } \\
\end{array}$ & \multicolumn{3}{|c|}{$\begin{array}{l}\text { フレックスタイム, (基本 } 8: 30 \sim 17: 30) \\
\text { コアタイム } 10: 00 \sim 15: 00, \text { 昼休み 12:00〜13:00 }\end{array}$} \\
\hline & その他 & \multicolumn{3}{|c|}{ 社員食堂有り } \\
\hline \multirow{5}{*}{$\begin{array}{l}\text { U } \\
\text { ビ } \\
\text { ル }\end{array}$} & 場 所 & 東京都 & 敷地面積 & $4,980 \mathrm{~m}^{2}$ \\
\hline & 途 & 事務所 (テナントビル) & 建築面積 & $4,390 \mathrm{~m}^{2}$ \\
\hline & 規 模 & 地上23階, 地下5階 & 延床面積 & $120.500 \mathrm{~m}^{2}$ \\
\hline & 業 種 & \multicolumn{3}{|l|}{ テナント多社 } \\
\hline & その他 & \multicolumn{3}{|l|}{ レストラン有り } \\
\hline \multirow{5}{*}{$\begin{array}{l}C \\
\text { ビ } \\
ル\end{array}$} & 場 所 & 東京都 & 敷地面積 & $4,010 \mathrm{~m}^{2}$ \\
\hline & 途 & 事務所 (テナントビル) & 建築面積 & $2,420 \mathrm{~m}^{2}$ \\
\hline & 模 & 地上21階，地下3階 & 延床面積 & $26.500 \mathrm{~m}^{2}$ \\
\hline & 種 & \multicolumn{3}{|c|}{ 建設会社 } \\
\hline & $\begin{array}{ll}\text { 就 } & \text { 業 } \\
\text { 時 } & \text { 間 }\end{array}$ & \multicolumn{3}{|c|}{$\begin{array}{l}\text { テナント } 1 \text { 社 } \\
8: 30 \sim 17: 15, \text { 昼休み } 12: 00 \sim 13: 00\end{array}$} \\
\hline
\end{tabular}

* 東京都立大学大学院 教授・工博

** 宇都宮大学大学院 助教授・工博

*** 宇都宮大学 文部技官
Prof., Graduate School of Engineering, Tokyo Metropolitan University, Dr. Eng. Assoc. Prof., Graduate School of Engineering, Utsunomiya University, Dr. Eng. Technical Official, Dept. of Architecture and Civil Engineering, Faculty of Engineering, Utsunomiya University 
ものである。また着衣量については、季節差のほか時刻変動、通勤 時と執務時の違いにも着目して調查を行った。なお、本論文は文献4） 〜7)をもとに加筆修正したものである。

\section{2. 睭疽建彻概要}

調㚗建物は、東京にあるオフィスビル 3 棟て、建物概要を表 -1 に、調査項目と調査日時を表ー 2 に示す。建物を 1 社のみで使用し ているNビルとCビルでは、入退館者数之主要階の在室人員数、着 衣量、OA 機器台数の調査を行い、テナント多社が使用しているU

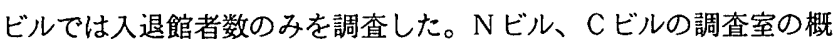
要を表ー 3 に示す。 $N$ ビル、Cビルとも部屋分割を意識的に少なく した内部設計となっており、執務空間・打ち合わせ空間・OA空間 が低いパーティションで区切られるのみで、各階 1 つの大部屋に収 められている。Cビルは、夏期調査時には11〜18階が空室で10階以 下を調査対象とした。冬期調查時には11階と17階一部のスペースが 空室であったが、延べ床面積の $94 \%$ 使用されていた。
蒜一2 調㸖日封

\begin{tabular}{|c|c|c|}
\hline 調疽项目 & $N$ ビル & \\
\hline 入退㿟务鲷盗 & 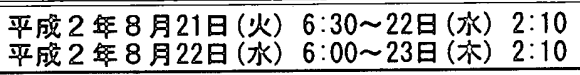 & * \\
\hline 在室人貝鲷㿽 & 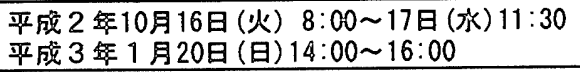 & \\
\hline 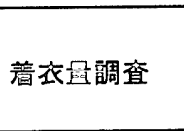 & 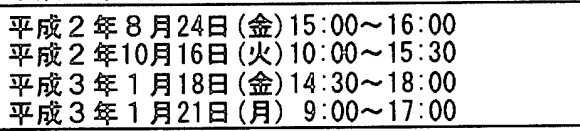 & * \\
\hline \multirow[t]{2}{*}{ OA 禨器調㿽 } & 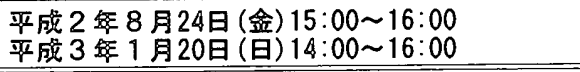 & * \\
\hline & Uビル & \\
\hline \multirow[t]{2}{*}{ 入退館凅舅亘 } & 平成 4 1 月24日 (金) $6: 30 \sim 25$ 日 (土) $3: 00$ & 象 \\
\hline & $c$ ビル & \\
\hline 入退筫省賙䆝 & 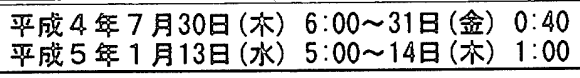 & $*$ \\
\hline 在室人員嗝畜 & 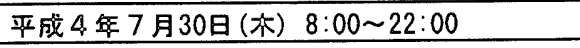 & 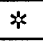 \\
\hline 着衣量㽬 & 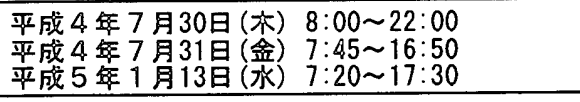 & * \\
\hline OA蟣器調㸖 & $\begin{array}{l}\text { 平成 } 4 \text { 月31日 (金) } 15: 30 \sim 16: 50 \\
\text { 平成 5 月20日 (水) } 15: 30 \sim 16: 50 \\
\end{array}$ & 计 \\
\hline
\end{tabular}

\section{3. 入退館及び在管人員变動特㤬}

事務室の在室人員変動は、室により多少の違 いがある。出勤時間帯や残業時間帯について は、エントランスでの入退館者調査によって得 られる在館人員変動を調べると、その建物の平 均的な在室人員変動の特徵を読みとることがで きる。また在館人員変動を得るために調査する 入退館者数の変動は、冬期のエントランス外気 侵入量に重大な影響を及ぼすエントランス開口 面積変動の予測のための基礎デー夕となり得る 点から重要である。 3 棟の建物について、一般 出入り可能なエントランス及び地下駐車場等か らの入館者、退館者の累積値を 5 分もしくは 10 分 間隔にカウントし、平日の在館人員変動を求め た結果を図一 1 に示す。入退館者数は10分間隔の 変動で示し、在館者数とも単位延床面皘当たり 人数で表した。Cビルについては、冬期のデー タを示した。

3 樏のビルとも、出社はエントランス扉の開 錠時刻（N,Cビル：7:30, Uビル：7:00）に合 わせて始まり、最大在館者数は建物により 0.025 〜0.04人/ $\mathrm{m}^{2}$ となった。就業時間が固定制のCビ

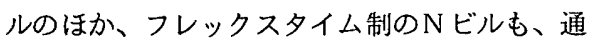
勤ピークが8:30直前の10分間に極端に発生し、と もに $0.09 人 / \mathrm{m}^{2} \circ 10$ 分の入館者となった。レスト ランのないCビルと、外部から利用できるレス トランをもつUビルは、昼休み時間帯の入退館 が激しい。在館状況を調查日の最大在館者数に 対する在館率でみると、どのビルも、9〜10時の 間に在館率 $95 \%$ に達し、また 12 時の在館率は建物 により 45〜90\%となった。17時以降の在館率の減 少は、18時に $80 \% 、 19$ 時に50\%、20時に30\%、22 時に $10 \%$ 程度で建物による減少傾向の違いはあ

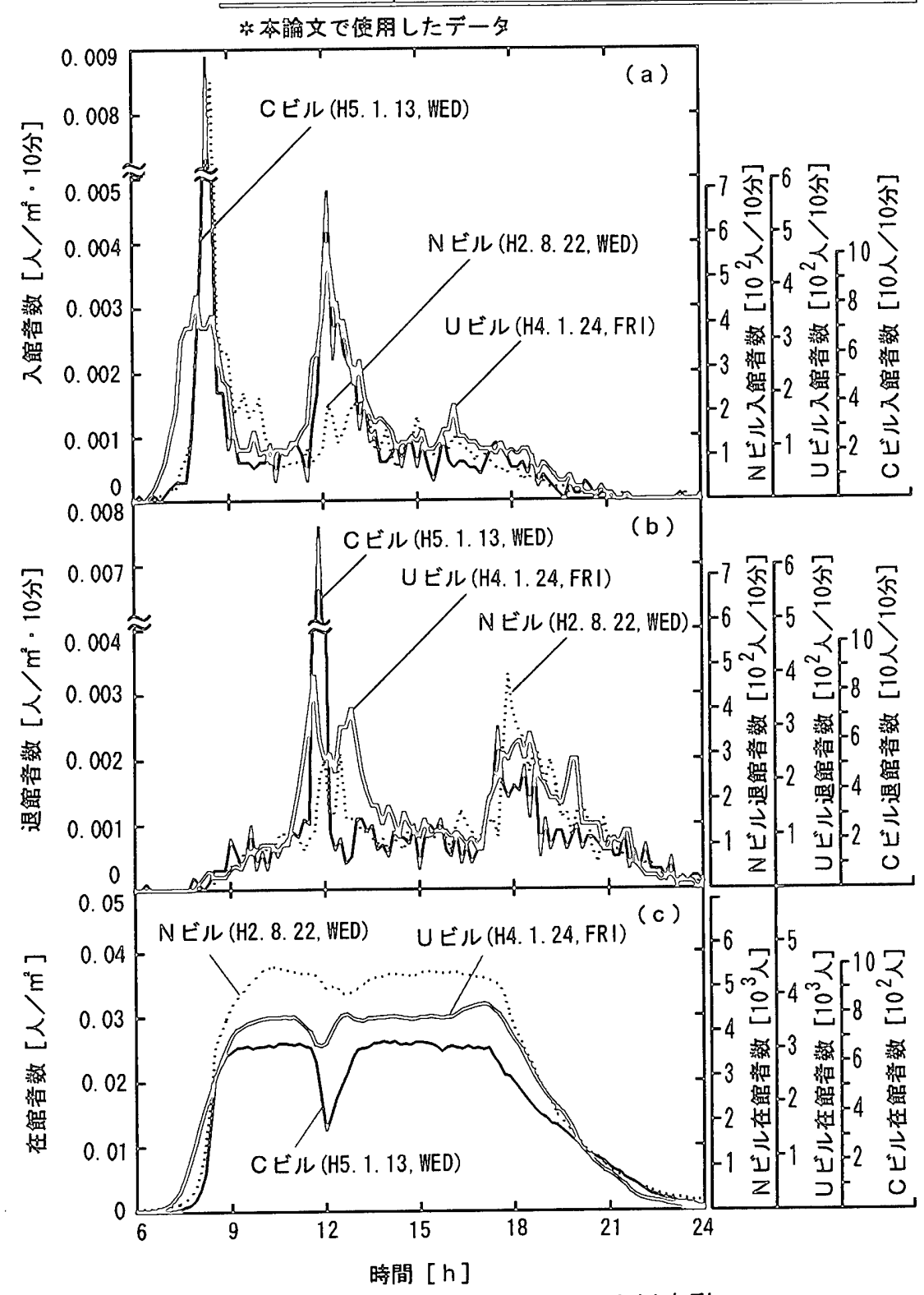

图一-1 入退館者数及び在館者数の時刻变動 
まりなかった。

\section{4. 在室人員変動特性}

$\mathrm{N}$ ビル，Cビルについて主要な階の定員や在室人員変動を調査し た。定員は、使用されている事務机の数や座席表から調べ、結果を 表一 3 に記載した。在室人員変動調查は、7時以前はほとんど在室者 がないので8時より開始し、30分もしくは 1 時間間隔に各室を巡回し 在室者数をカウントした。

近年は事務机のほかにO A 机も混在配置されることが多くなり、 またN、Cビルのように応接や打合わせのためのスペースが小部屋 として分離されずに事務室の一部に含まれる場合も多くなっている。 そこて、Nビルの場合には、定員を表す事務用座席数のほか、打合 わせ用、 $\mathrm{OA}$ 用座席数も調査した。図一 2 に示すように、Nビルの

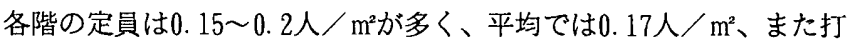
合わせ用座席数、O A 用座席数はそれぞれ0.08、0.05人/ $\mathrm{m}^{2}$ となっ た。図 -4 はC ビルの各階定員である。Cビルの場合は座席表より

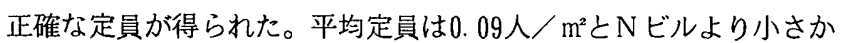
った。

各階の在室人員の時刻変動を図ー $3 、 5$ に示す。調査日の最大在 室人員は、室により $\mathrm{N}$ ビルは $0.09 \sim 0.13$ 人 $/ \mathrm{m}^{2} 、 \mathrm{C}$ ビルは0.06〜 0.11 人/ $\mathrm{m}^{2}$ となり、昼休みには0.03 0.08人/ $\mathrm{m}^{2} に$ 減少する。両ビ ルの各建物全体の平均在室人員変動と定員に対する在室率変動を表

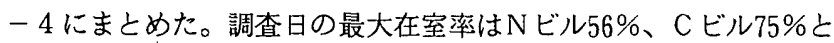
建物によりかなり差があることが分かった。

\section{5．着衣量の変動特性}

着衣量は、温冷感に大きな影響を与えるが、執務時において人々 は様々な衣服で作業を行っている。また、室内環境によっても異な ると思われる。しかし、各季節の各種事務作業時の着衣状況を観察 してみると夏期・中間期において男性は、ワイシャツ半袖，ワイシ ャツ長袖，ワイシャツ+ベスト，まれに背広（薄手）姿で作業を行

\begin{tabular}{|c|c|c|c|c|c|c|c|}
\hline \multicolumn{4}{|c|}{ 表一 3} & \multicolumn{2}{|c|}{ 調査室概要 } & & \\
\hline \multicolumn{4}{|c|}{ Nビル } & \multicolumn{4}{|c|}{ Cビル } \\
\hline \multicolumn{4}{|c|}{ 調查日:1991年 1 月20日 } & \multicolumn{4}{|c|}{ 調查日：1993年 1月13日 } \\
\hline 階 & 室 & $\begin{array}{l}\text { 室床面積 } \\
{\left[\mathrm{m}^{2} / \text { 階 }\right]}\end{array}$ & $\begin{array}{c}\text { 定員 } \\
\text { [人/階] }\end{array}$ & 階 & \begin{tabular}{|l} 
室 \\
数 \\
\end{tabular} & $\begin{array}{l}\text { 室床面積 } \\
\left.\text { [ } \mathrm{m}^{2} / \text { 階 }\right]\end{array}$ & $\begin{array}{c}\text { 定 員 } \\
\text { [人/階] }\end{array}$ \\
\hline 6 & 2 & 2,133 & 412 & \multirow{3}{*}{$\begin{array}{r}3 \\
4 \\
5 \\
6 \\
7 \\
8 \\
9 \\
10 \\
\end{array}$} & \multirow{3}{*}{$\begin{array}{l}2 \\
2 \\
2 \\
2 \\
2 \\
2 \\
2 \\
2\end{array}$} & \multirow{3}{*}{$\begin{array}{l}819 \\
632 \\
819 \\
632 \\
819 \\
632 \\
819 \\
632 \\
\end{array}$} & \multirow{3}{*}{$\begin{array}{r}88 \\
62 \\
87 \\
68 \\
104 \\
57 \\
33 \\
44\end{array}$} \\
\hline $\begin{array}{r}7 \\
8 \\
9 \\
10 \\
\end{array}$ & $\begin{array}{l}2 \\
2 \\
2 \\
2 \\
\end{array}$ & $\begin{array}{l}2,089 \\
1,972 \\
2,040 \\
1,715 \\
\end{array}$ & $\begin{array}{l}408 \\
363 \\
452 \\
264 \\
\end{array}$ & & & & \\
\hline \multirow{3}{*}{$\begin{array}{l}19 \\
21 \\
22 \\
23 \\
24 \\
25 \\
26 \\
\end{array}$} & \multirow{3}{*}{$\begin{array}{l}1 \\
1 \\
1 \\
1 \\
1 \\
1 \\
1\end{array}$} & \multirow{3}{*}{$\begin{array}{l}1.613 \\
1.613 \\
1,581 \\
1,581 \\
1.581 \\
1,581 \\
1,576 \\
\end{array}$} & \multirow{3}{*}{$\begin{array}{l}231 \\
221 \\
220 \\
229 \\
248 \\
221 \\
267 \\
\end{array}$} & & & & \\
\hline & & & & $\begin{array}{l}\text { 下層 } \\
\text { 階 }\end{array}$ & 16 & 5,804 & 543 \\
\hline & & & & \multirow{3}{*}{$\begin{array}{l}12 \\
13 \\
14 \\
15 \\
16 \\
17 \\
18\end{array}$} & \multirow[t]{3}{*}{$\begin{array}{l}2 \\
1 \\
1\end{array}$} & \multirow{3}{*}{$\begin{array}{l}632 \\
410 \\
316 \\
819 \\
632 \\
410 \\
316\end{array}$} & \multirow{3}{*}{$\begin{array}{l}48 \\
20 \\
32 \\
66 \\
46 \\
40 \\
37\end{array}$} \\
\hline \multirow[t]{4}{*}{ 合計 } & 17 & 21,075 & 3,536 & & & & \\
\hline & & & & & & & \\
\hline & & & & $\begin{array}{l}\text { 上層 } \\
\text { 階 } \\
\end{array}$ & 10 & 3.535 & 289 \\
\hline & & & & 合計 & 26 & 9,339 & 832 \\
\hline
\end{tabular}

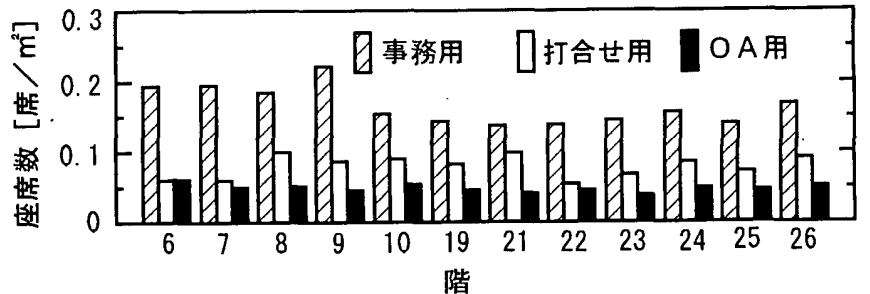

図一2Nビル座席数

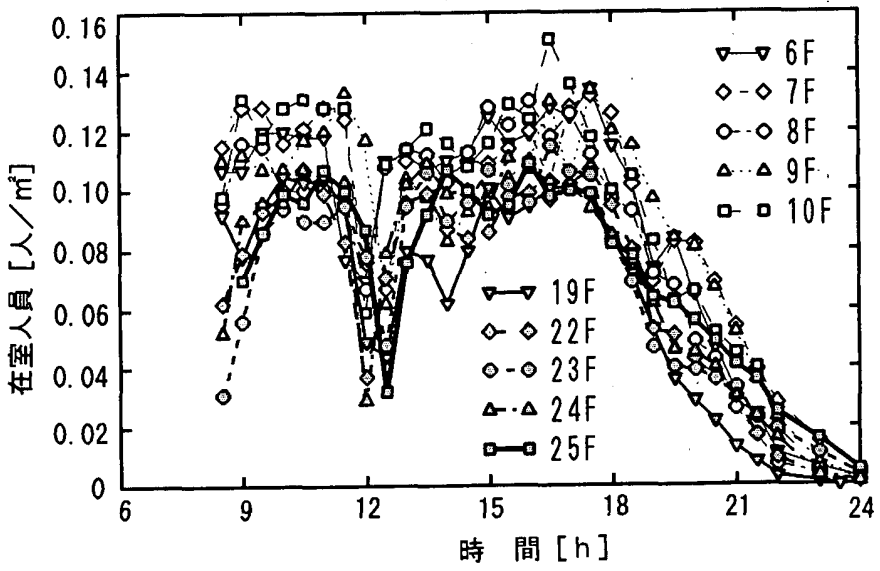

図ー3Nビル在室人員の時刻変動

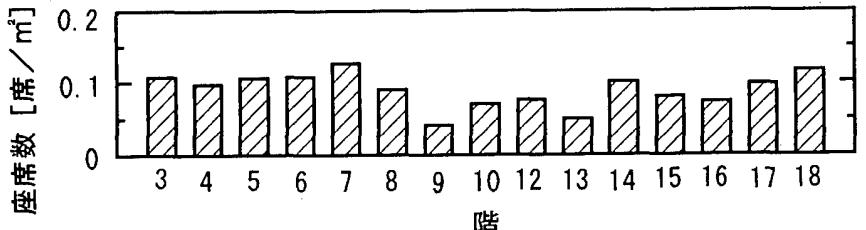

図-4 Cビル座席数

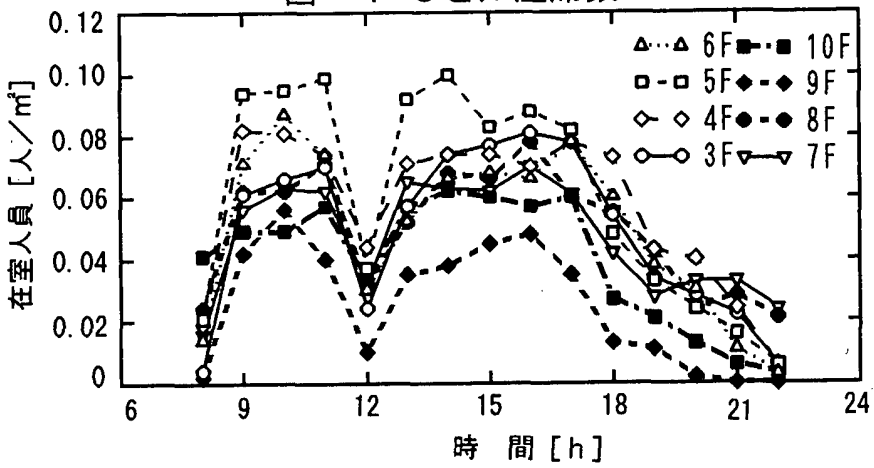

図一 5 Cビル在室人員の時刻変動 表一4 在窒人員及び定員に対する割合の時刻変動

\begin{tabular}{r|c|c|c|c}
\hline \multirow{2}{*}{ 時間 } & \multicolumn{2}{|c|}{$\mathrm{N}$ ビル } & \multicolumn{2}{c}{$\mathrm{C}$ ビ ル } \\
\cline { 2 - 5 } & $\begin{array}{c}\text { 在室人員 } \\
{[\text { 人] }}\end{array}$ & $\begin{array}{c}\text { 定員に対する } \\
\text { 割合 [\%] }\end{array}$ & $\begin{array}{c}\text { 在室人員 } \\
\text { [人] }\end{array}$ & $\begin{array}{c}\text { 定員に対する } \\
\text { 割合 [\%] }\end{array}$ \\
\hline 8 & 886 & 29.1 & 96 & 17.8 \\
\hline 9 & 1.513 & 49.6 & 374 & 69.4 \\
\hline 10 & 1,608 & 52.7 & 406 & 75.3 \\
\hline 11 & 1.611 & 52.8 & 397 & 73.7 \\
\hline 12 & 1.076 & 35.3 & 172 & 31.9 \\
\hline 13 & 1.535 & 50.3 & 351 & 65.1 \\
\hline 14 & 1,479 & 48.5 & 397 & 73.7 \\
\hline 15 & 1.617 & 53.0 & 389 & 72.2 \\
\hline 16 & 1.701 & 55.8 & 405 & 75.1 \\
\hline 17 & 1.715 & 56.2 & 384 & 71.2 \\
\hline 18 & 1.437 & 47.1 & 264 & 49.0 \\
\hline 19 & 995 & 32.6 & 178 & 33.0 \\
\hline 20 & 790 & 25.9 & 139 & 25.8 \\
\hline 21 & 477 & 15.6 & 120 & 18.9 \\
\hline 22 & 246 & 8.1 & 51 & 9.5 \\
\hline
\end{tabular}


っている。また、冬期にもワイシャツ半袖, ワイシャツ長袖, ワイ シャツ+ベスト，セーターもしくは背広（厚手）姿で作業を行って いることから、各種事務作業時の着衣量を表一 5 のように分類して、 目視調查により各分類に該当する人数を集計した。背広姿の時にワ イシャツ半袖か長袖かどうかとか、下着の種類はどうかなどの違い は存在するが、表中の值が代表的な値亡考え、調査人数を多くする ことによって妥当性を高めることを重視した。女性については、服 装の種類が多様であるが調査の都合上男性と同様に分類した。Nビ ル調査では、女性が少数であるため男女を区別せず同じ着衣量分類

表一5 着衣量調盗に分ける基準着衣量

\begin{tabular}{|c|c|c|c|c|}
\hline & \multicolumn{2}{|c|}{ 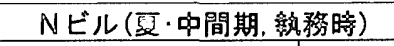 } & \multicolumn{2}{|l|}{ Nビル（疼期，解務時) } \\
\hline & 男。立胫 & clo侐 & 男。玄懏 & clo谊 \\
\hline A1 & 背広 & 0.95 & 背広, セ一タ一 & 1.00 \\
\hline B1 & ベスト & 0.80 & ベスト & 0.80 \\
\hline C1 & ワイシャツ.プ方スス長神 & 0.70 & ワイシャ゙リブラウス長袖 & 0.70 \\
\hline D1 & ワイジリリプ゙ラスス腕まくり & 0.65 & ワイジャツプラウス腕まくり & 0.65 \\
\hline \multirow[t]{3}{*}{ E1 } & ワイジッツプラウス半褞 & 0.60 & ワイシャツリブラウス羊緢 & 0.60 \\
\hline & \multicolumn{4}{|c|}{ 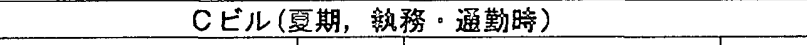 } \\
\hline & 男性 & clo值 & 许 & clo䈯 \\
\hline A 2 & 背広, セータ一 & 0.95 & スーツープラウス数 & 0.75 \\
\hline B2 & ワイシが長袖 & 0.70 & 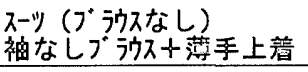 & 0.65 \\
\hline $\mathrm{C} 2$ & ワ仿り腕まくり & 0.65 & 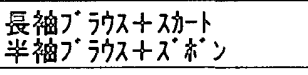 & 0.55 \\
\hline D 2 & 7价やツ半袖 & 0.60 & $\begin{array}{l}\text { 半袖プラウススースカート } \\
\text { 袖なしフラウスーズボン }\end{array}$ & 0.50 \\
\hline \multirow[t]{3}{*}{ E2 } & ワイシやリ半袖・初多なし & 0.55 & 襣なしブラウスス 坊ート & 0.45 \\
\hline & \multicolumn{4}{|c|}{ Cビル (冬期, 㛙務時) } \\
\hline & 男懏 & clo值 & 如等 & clo値 \\
\hline A 3 & 背広ナベスト & 1.10 & 背広十ベスト， & 1.05 \\
\hline B3 & 背広，セータ一 & 1.00 & 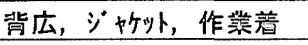 & 0.90 \\
\hline C3 & ベスト & 0.80 & ベストセーター & 0.75 \\
\hline D3 & ワ隹やり長䙟 & 0.70 & プ汸ス長襕 & 0.65 \\
\hline \multirow[t]{3}{*}{ E3 } & ワ隹や゙腕まくり & 0.65 & ブラウ腕まくり & 0.60 \\
\hline & \multicolumn{4}{|c|}{ Cビル(冬期, 通勤時) } \\
\hline & 男怪 & clo徝 & 媇诠 & clo檤 \\
\hline A4 & $\begin{array}{l}\text { オーパー (前止) + } \\
\text { マフラー }\end{array}$ & 1.50 & $\begin{array}{l}\text { オーパー（前止）+ } \\
\text { マフラー }\end{array}$ & 1. 40 \\
\hline B4 & オーバー（前止） & 1.40 & オーパー（前止） & 1. 30 \\
\hline $\mathrm{C} 4$ & オーバー（湔開） & 1.35 & オーパー（前開） & 1.20 \\
\hline D4 & トレンチコート（前閶） & 1.25 & トレタコート（前開） & 1.10 \\
\hline E4 & コートなし & 1.10 & コートなし & 1.05 \\
\hline
\end{tabular}
㳖 -6 着育量調疽人改

\begin{tabular}{|c|c|c|c|c|c|c|c|}
\hline \multirow{2}{*}{$\begin{array}{l}\text { 調䆝 } \\
\text { 犍物 }\end{array}$} & \multirow{2}{*}{ 調窒期間 } & \multirow{2}{*}{ 裯㸖時 } & \multirow{2}{*}{$\begin{array}{l}\text { 胡 疽 } \\
\text { 人数 } \\
\text { [人] }\end{array}$} & \multicolumn{4}{|c|}{ 祸周㸖室 } \\
\hline & & & & $\begin{array}{l}\text { 聜徽 } \\
\text { [空] }\end{array}$ & $\begin{array}{c}\text { 平均 } \\
\text { [人] }\end{array}$ & [品离 & $\begin{array}{c}\text { 是 諙 } \\
\text { [人] }\end{array}$ \\
\hline$N$ & 要 期 & 崪務暧 & 1,016 & 11 & 92 & 126 & 69 \\
\hline ビ & 中間期 & 新敄時 & 1,526 & 10 & 153 & 200 & 119 \\
\hline ル & 纺 期 & 㰵矜绶 & 1,640 & 12 & 137 & 186 & 96 \\
\hline \multirow{4}{*}{$\begin{array}{l}C \\
⺊\end{array}$} & \multirow{2}{*}{ 夏 期 } & 颌矜時 & 387 & 16 & 24 & 33 & 13 \\
\hline & & 通勤時 & 418 & - & - & - & - \\
\hline & \multirow{2}{*}{ 笭 期 } & 勃敄暗 & 616 & 28 & 22 & 41 & 7 \\
\hline & & 通勤時 & 777 & - & - & - & - \\
\hline
\end{tabular}

注）Nビルにおいて調盗室の檤は階全体の合竍谊 賙盗日暗 Nビル：平成 2等 8月24日(金) 15:00 16:00 平成 2 10月16日 (火) 10:00 15:30 平成 3 年 1 月18日 (金) 14:30 18:00

Cビル：平成 4 年 7月30日 (木) 15:30 16:50 平成 5 年 1 月13日(水) $16: 10 \sim 17: 30$
を使用し、Cビル調査では男女別に分類を設けた。また、通勤時に おいても着衣状況亡着衣量の間に多少誤差が含まれるものの、表一 5 のように着衣量を分類することができる。

着衣量調査において表一 5 を基準着衣量とし、通勤時には各扉か ら入館する人、執務時には各事務室において各種作業及び打ち合わ せを行っている人のうち、それぞれの分類に該当する人数をカウン 卜し、通勤から作業に移る際の着衣状況や朝から夕方への着衣状況 の時刻変動及び季節変動特性を調查した。時刻変動の調査は、在室 人員調査と同様、30分もしくは 1 時間間隔に各室を巡回し人数を力

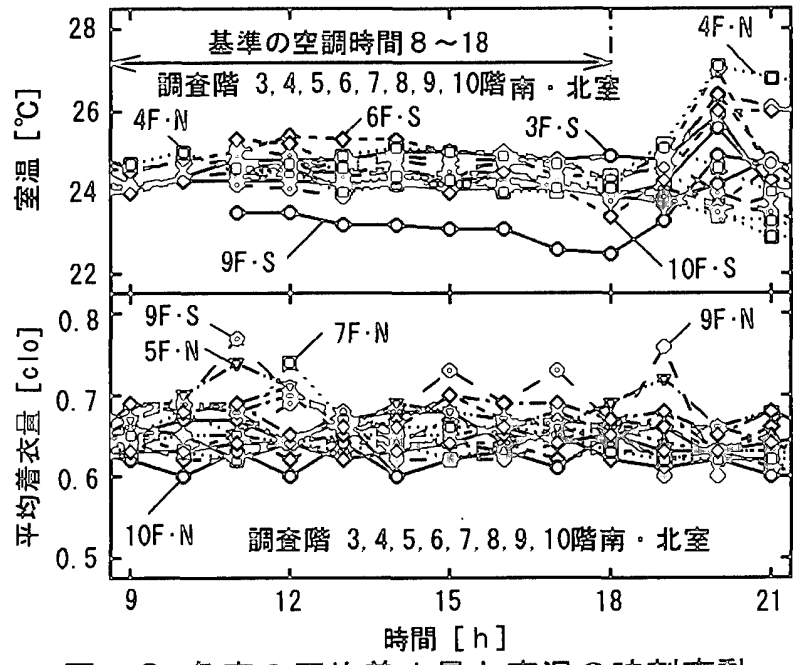

图－6各室の平均着衣量と空温の時刻変鲠 (Cビル。夏期)

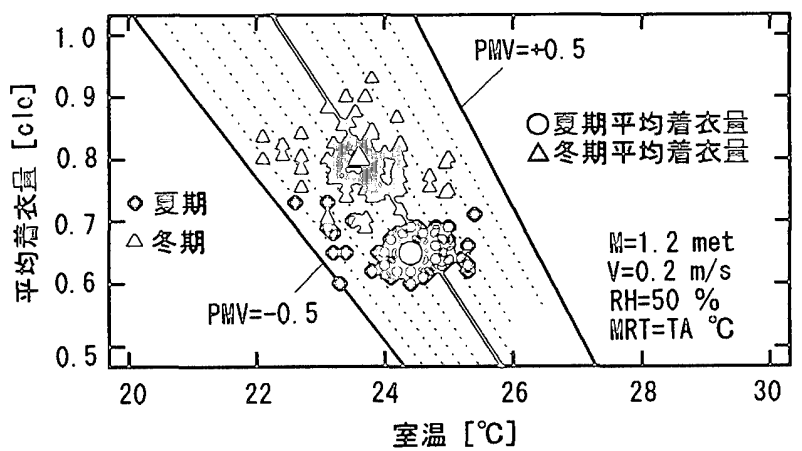

图一7 各室の平均前衣量と室温の相閏（のビル）

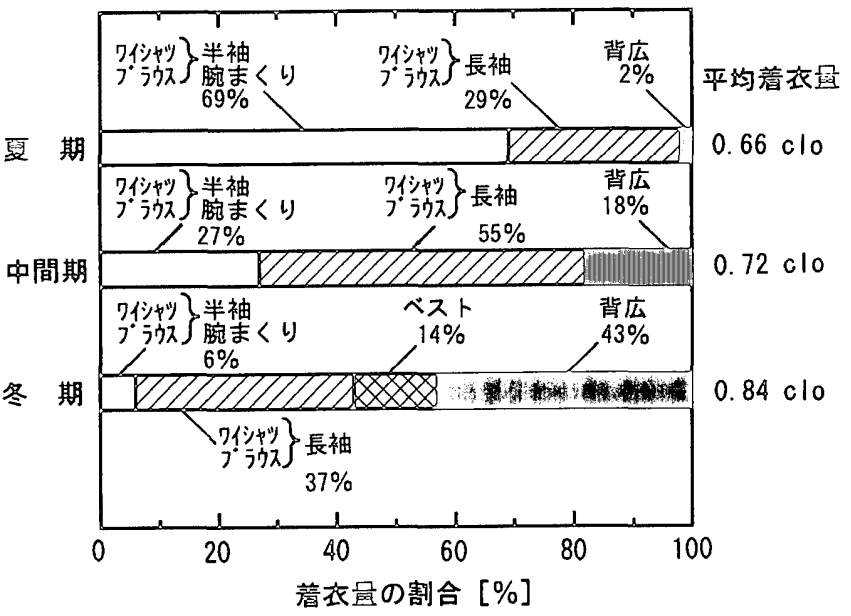

図-8 各季節の㸉務時の着衣量別人数（Nビル） 
表ー7 各季節における執務時及び通勤時の着衣量

\begin{tabular}{|c|c|c|c|c|c|c|}
\hline & & & & $\begin{array}{c}\text { 調查人数 } \\
\text { [人] }\end{array}$ & $\begin{array}{c}\text { 平均着衣量 } \\
\text { [clo] }\end{array}$ & {$\left[\begin{array}{c}\text { 室 ·外気温 } \\
{\left[{ }^{\circ} \mathrm{C}\right]}\end{array}\right.$} \\
\hline $\mathrm{N}$ & 夏 期 & 執務時 & 男 & 1,016 & 0.65 & 25.2 \\
\hline ビ & 中間期 & 執務晆 & 男 · 女 & 1,526 & 0.70 & 24.8 \\
\hline ル & 冬 期 & 執務時 & 男·女 & 1,640 & 0.85 & 23.6 \\
\hline \multirow{8}{*}{ C } & \multirow{4}{*}{ 夏 期 } & \multirow{2}{*}{ 通勤時 } & 男 & 283 & 0.65 & \multirow{2}{*}{28.3} \\
\hline & & & 女 & 135 & 0.55 & \\
\hline & & \multirow{2}{*}{ 執務時 } & 男 & 266 & 0.65 & \multirow{2}{*}{24.4} \\
\hline & & & 女 & 121 & 0.55 & \\
\hline & \multirow{4}{*}{ 冬 期 } & \multirow{2}{*}{ 通勤时 } & 男 & 571 & 1. 35 & \multirow{2}{*}{2.1} \\
\hline & & & 女 & 206 & 1.30 & \\
\hline & & \multirow{2}{*}{ 執務時 } & 男 & 451 & 0.80 & \multirow{2}{*}{23.6} \\
\hline & & & 女 & 165 & 0.75 & \\
\hline
\end{tabular}

※通勤時の着衣量 : 朝の出社時の屋外の服装

ウントした。また、同時に各事務空の温度及び外気温も計測し た。表一 6 に着衣量調査人数を示す。また、各事務室における 執務者の着衣量の平均値を平均着衣量とし、図ー6にCビルに おける夏期の各室の平均着衣量と室温の時刻変動を示す。各事 務室の執務時の平均着衣量は、0.6 0.7cloで時刻的に大きな変 動は見られない。その時の室温は $25^{\circ} \mathrm{C}$ 程度であった。冬期も同 様に時刻的な変動は見られなかった。

図ー7にCビルにおける各室の平均着衣量と室温の相関を示 す。夏期，冬期とも各事務室の平均着衣量は、 $\mathrm{PMV} \pm 0.5$ の範 囲に分布している。夏期の平均着衣量は0.62c1o，冬期は0. 80c ○であった。Nビルにおいても同様な結果が得られた。

図ー8にNビルの各季節の執務時の着衣量別人数を示す。夏 期において、ワイシャツ半袖, 腕まくりで作業を行っている人 が70\%を占め、平均着衣量としては0.66c10となっていた。冬期 においては、40\%の人が背広もしくはセーターで作業を行って いた。また、約 $40 \%$ のがワイシャツで作業を行っており、平 均着衣量亡しては0.84 cloとかなり低い值で、一般的に言われ ている程季節差がないことがわかった。

図一 9，10にC ビルの夏期，冬期の通勤時及び執務時の着衣 量別人数を示す。夏期において男性の平均着衣量は、通勤時に 0.67cloであったものが執務時には0. $65 \mathrm{cl} 10$ と若干薄着となっている。 逆に女性は通勤時に0.54c10であったものが執務時には0.56c10と厚 着になる傾向となっている。女性の場合、少数ではあるが執務時に 作業用の上着を着たり、膝掛けを使用している。また、夏期，冬期 共に女性は男性より薄着である。

以上、表一 7 に各季節における執務時及び通勤時の平均着衣量を 示す。数值の精度を考虑して、0.05clo刻みの数値で示した。

\section{OA機器使用状況}

事務所ビルのOA化に伴い、ネットワーク化された各種端末機器 やパーソナルコンピュータ（以下コンピュータ），ワードプロセッ サ(以下ワープロ)，コピー機などの各種電子機器が導入され室内 発熱密度が増加している。また、それに伴いV D T 作業が多くなり 照明器具なども变化している。そこでンピュー夕（各種端末も含 む）ワープロ，プリンタ，ファクシミリ，コピー機及び天井照明， 手元照明器具等を各室を巡回して台数をカウントし、機器発熱量を
通勤（男）

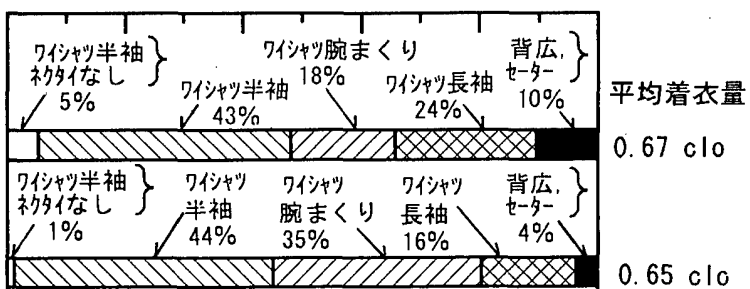

通勤（女）

執務（女）

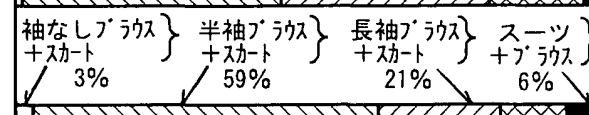

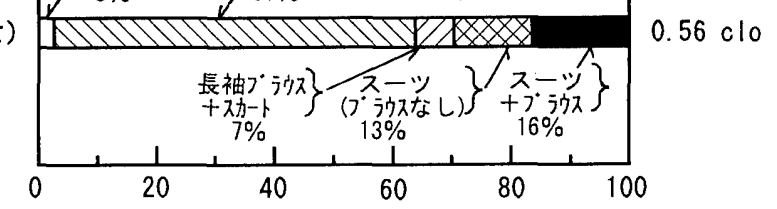

着衣量の割合 [\%]

図－9 通勤時と執務時の着衣量の割合（ Cビル・夏期）

通勤（男)

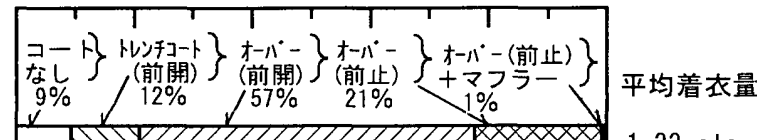

執務（男）

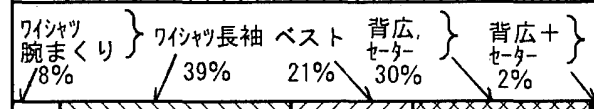
$1.33 \mathrm{clo}$

通勤（女）

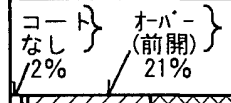
$0.80 \mathrm{clo}$

執務（女）

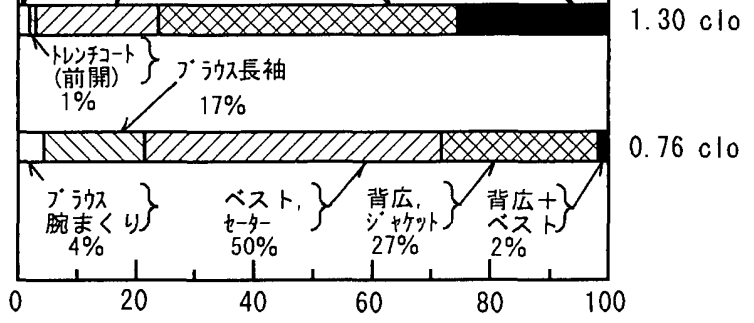

着衣量の割合 $[\%]$

図一-10 通勤時と執務時の着衣量の割合（Cビル・冬期）

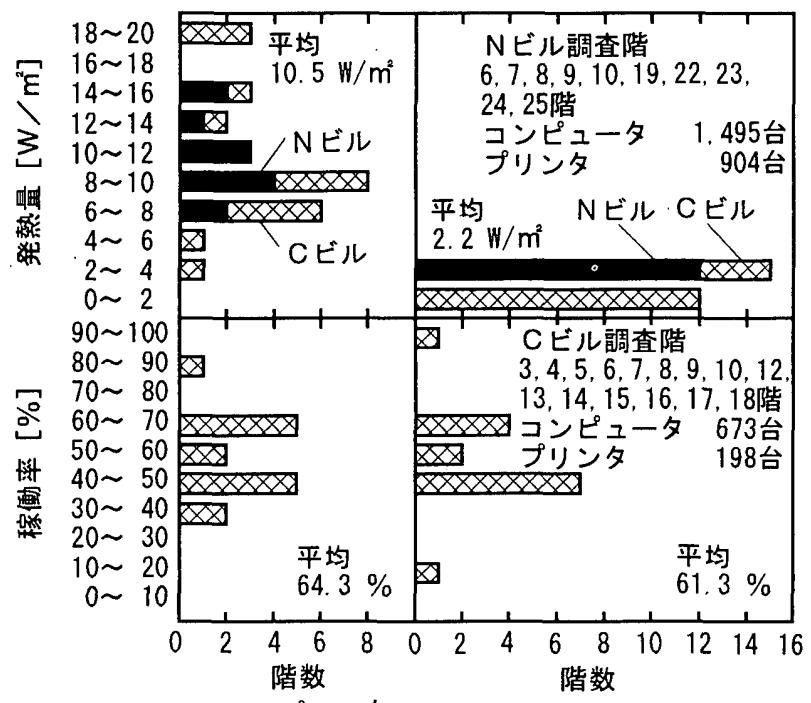

(a) コンピュータ

(b) プリンタ

図ー11 コンピュータとプリンタの発熱量及び稼働率 
調査した。また、Cビルにおいてその電源の入っているものを稼働 しているものとし、その台数も調查した。

図ー11にNビルとCビルの各事務室におけるコンピュータ及びプ リンタの発熱量及び稼働率を示す。また、表一 8 にコンピュータ， プリンタ,コピー機の設㯰台数と発熱量及び稼働率を示す。なお、 各O A 機器の発熱量は、 $\mathrm{N}$ ビル， $\mathrm{C}$ ビルに設置してある代表的な機 器の消費電力量のカタログ値をもとに、コンピュータ（ここては、 パソコン, ワープロ, 端末機などの総称） $150 \mathrm{~W} /$ 台, プリンタ 70 $\mathrm{W} /$ 台, コピー機 $1500 \mathrm{~W} /$ 台, 手元照明 $27 \mathrm{~W} /$ 台, 天井照明 $40 \mathrm{~W}$ /台として算定した。

コンピュータの設置台数は、Nビル 0.071 台 $/ \mathrm{m}^{2}$, Cビル 0.070

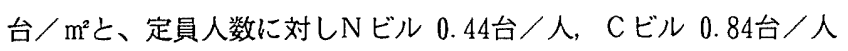
となっている。プリンタの設置台数はコンピュータの約半分の 0.32 台 $/ \mathrm{m}^{2}$ となっている。コピー機の設置台数は、0.004台 / $\mathrm{m}^{2}$ と少ない ものの高い稼働率で稼働している。また、発熱量としてコンピュー 夕はNビル $10.6 \mathrm{~W} / \mathrm{m}^{2}$, Cビル $10.4 \mathrm{~W} / \mathrm{m}^{2}$ 、稼働率としては、コ ンピュータ,プリンタ共に約 $60 \%$ となっている。

表一 9 にCビルの照明器具の設置台数と発熱量及び稼働率を示す。 タスク・アンビエント照明を基本としていることから天井照明が $12.5 \mathrm{~W} / \mathrm{m}^{2}$ と少ないが、各事務室の平均照度測定值は $370 \sim 5701 \mathrm{x}$ であった。手元照明の稼働率は、36\%と在室者の約半分であること がわかった。

7. 絔

1991〜1993年にかけて、東京に建つ、延床面積 27,000〜145, 000 の事務所ビル 3 植において、在館者 ·在室者、着衣量変動、O A 機 器使用状況の調查を行った。調査した 3 榑のビルは、OA化オフィ スビルとして平均的な使われ方をしていると判断でき、また調査室 床面積は $30,000 \mathrm{~m}^{2} に な り 十$ 分なデー夕が得られたので、以下に示す 知見は一般的な O A 化ビルの使われ方として、設計や解析に利用可 能と考えられる。

1)調查日の単位延床面樻当たりの最大在館者数は、建物により0.025 〜0.04人/ $\mathrm{m}^{2}$ となった。どのビルも9 10時までに最大在館者数の $95 \%$ が出社し、17時以降は、最大在館者数に対し、18時に $80 \%$ 、 19 時に $50 \%$ 、20時に $30 \% 、 22$ 時に10\%と減少し、建物による城少 傾向の違いはあまりなかった。

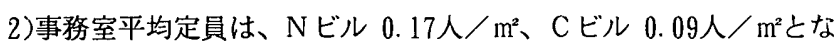
った。定員に対する在室率変動をそれぞれのビルについて得た。

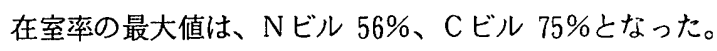

3) 2 槙のビルの執務時の着衣量調査結果は同様の傾向を示した。平 均着衣量は、夏期に男性 $0.67 \mathrm{clo}$ 、女性 $0.54 \mathrm{clo}$ 、冬期に男性 $0.80 \mathrm{cl}$ 、女性 $0.76 \mathrm{clo}$ となり、李節差はそれほど大きくなく、ま た女性が男性より夏期にかなり薄着であることが明らかになった。

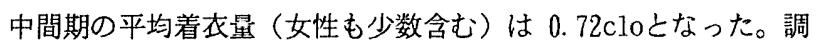
査室の室温と着衣量より P MVを予想したところ、よ゙の室も PM $\mathrm{V} \pm 0.5$ 以内の環境であったが、室温の違いに対し服装で調整して いる傾向は認められなかった。また時刻別の着衣量をみると、多 少の温熱感条件の变化に対しては着衣量調整を行っていないこと が分かった。

4)夏期の通勤時の着衣量は執務時とあまり变わらないが、わずかな

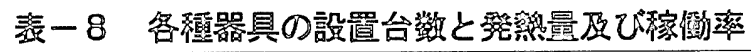

\begin{tabular}{|c|c|c|c|c|c|c|}
\hline \multirow{3}{*}{ コンピュータ } & \multirow{3}{*}{\begin{tabular}{|l|}
$N$ ビル \\
Cビル \\
\end{tabular}} & \multicolumn{2}{|c|}{$\begin{array}{l}\text { 設罟台数 } \\
\left.\text { [台 } / \mathrm{m}^{2}\right]\end{array}$} & \multicolumn{2}{|c|}{$\begin{array}{c}\text { 整熱㫣 } \\
{\left[\mathrm{W} / \mathrm{m}^{2}\right]}\end{array}$} & \multirow{3}{*}{ 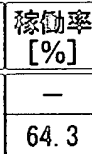 } \\
\hline & & 0.071 & \multirow{2}{*}{0.071} & 10.6 & \multirow{2}{*}{10.5} & \\
\hline & & 0.070 & & 10.4 & & \\
\hline \multirow{2}{*}{ プリンタ } & Nビル & 0.043 & \multirow{2}{*}{0.032} & 3.0 & \multirow{2}{*}{ 2. 2} & - \\
\hline & Cビル & 0.020 & & 1.4 & & 61.3 \\
\hline コピ一絒 & Cビル & \multicolumn{2}{|c|}{0.004} & \multicolumn{2}{|c|}{5.5} & 93.3 \\
\hline \multicolumn{7}{|l|}{ 运 -9} \\
\hline & & \multicolumn{2}{|c|}{$\begin{array}{l}\text { 設㯺台曔 } \\
{\left[\text { [台 } / \mathrm{m}^{2}\right]}\end{array}$} & 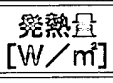 & \multicolumn{2}{|r|}{ 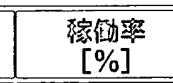 } \\
\hline \multirow{2}{*}{$\begin{array}{c}\text { 照 明 } \\
\text { (Cビル) }\end{array}$} & 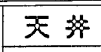 & \multicolumn{2}{|c|}{0.312} & 12.5 & \multicolumn{2}{|r|}{100.0} \\
\hline & 乎 元 & \multicolumn{2}{|c|}{0.100} & 2.7 & \multicolumn{2}{|r|}{36.2} \\
\hline
\end{tabular}

がら、男性は執務時より厚着、女性は薄着という傾向がある。冬 期の着衣量は男女とも $1.3 \mathrm{cl} 10$ 程度であった。

5)コンピュータの設置台数は、0.071台 $/ \mathrm{m}^{2} 、$ プリンタはその約半分

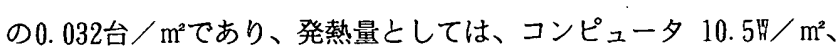

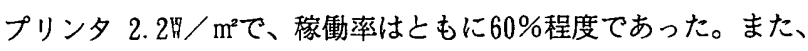
コピー機は、0.004台 / $\mathrm{m}^{2}$ と設置台数は少ないものの、発熱量は 5.5 月 $/ \mathrm{m}^{2}$ て、稼働率は約 $90 \%$ 亡高い。

\section{謝辞}

本調㚗にあたり、（㭠）日建設計（野原文男氏ほか）、N T T 都 市開発（株）（阿部政信氏ほか）、（株）大林組（平山昌宏氏ほか） の関係各位より多大なる御協力・御援助を睗った。ここに記して深 謝いたします。

\section{参考文献}

1)井上宇市、野部達夫、鈴木尚昭、滝村徹、富田滋、川島隆朗、島 潔、本田裕二 : オフィスビルの室内環境亡使われ方、空気調和・ 衛生工学会学術論文集、pp. 501 504、1987. 10

2)伊藤尚寛、久野覚、内山贲正、中原信生 : 省エネルギ庁舎ビルの 空調システムの性能評価に関する実態調查研究、空気調和・衛生 工学会論文集No. 35、pp. 45〜 58、1987. 10

3)木村建一、李夫、安田健一、野々瀬恵司、中島勝美、成田千里、 加藤智史 :インテリジェントビルにおける実測及び解析 第 1 報 室内の負荷特性について、空気調和・衛生工学会学術諓演会講演 論文集、pp. 773 776、1990.10

4)石野久旐、郡公子、佐藤豊 : 事務所ビルにおける在室人員・着衣 量及びOA 機器発熱量調査、日本建築学会大会学術講演梗概集、 pp. 1011 1012、1991. 9

5)石野久恓、郡公子、佐藤豊、斎藤佳樹郎：インテリジェントビル の熱環境亡発熱密度の変動特性、空気調和・衛生工学会学術講演 会講演諭文集、pp. 449 452、1991.10

6)石野久㢾、郡公子、佐藤豊、阿部政信、佐々木尚 : アトリウムを もつ建物の環境実測研究 第 1 報 入退館者状況亡エントランス 外気侵入量、日本建築学会大会学術講演梗概集、pp. 815 816、 1992.8

7)佐々木尚、石野久峧、郡公子、平山昌宏、野原文男 : オフィスビ ルの在館人員と着衣量の变動特性に関する研究、日本建築学会大 会学術講演梗概集、pp. 1503 1504、1993.9

(1997年 1 月 6 日原稿受理, 1997年 5 月 26 日採用決定) 